\title{
LEGAL SECURITY ON CELLPHONE TRADING THROUGH ELECTRONIC MEDIA IN INDONESIA ${ }^{\Omega}$
}

\author{
Aan Aswari, Syamsuddin Pasamai, Nurul Qamar and Ilham Abbas \\ Doctoral Program of Law Universitas Muslim Indonesia, Indonesia \\ E-mail: aanaswari@umi.ac.id
}

\begin{abstract}
The rapid growth of technology development brings impact on human life related to its utilization. This article analyzes legal security through several components in a cellphone trading through electronic media. This study is a conceptual idea and shows that the implementation of legal security in several components should provide solution to any potential conflicts. A good intention component should be applied to form an ideal legal relation from the beginning to the end and realization in performing its obligation reflect the concrete aspect. Warranty provides protection security for $r$ elated parties with some governing regulations during transaction. However, some other supporting components have not been effectively contribute to balance the utilization of technology in trading.
\end{abstract}

Keywords: legal security, trading, cellphone, electronic media

\begin{abstract}
Abstrak
Perkembangan teknologi yang semakin meningkat berakibat pada segi kehidupan manusia dalam pemanfaatannya. Artikel ini mengkaji kepastian hukum melalui beberapa komponen dalam sebuah transaksi jual beli telepon seluler melalui media elektronik. Kajian ini merupakan gagasan konseptual dan menunjukkan bahwa pelaksanaan kepastian hukum dalam beberapa komponen seharusnya dapat memberikan solusi terhadap konflik yang dapat timbul di kemudian hari. Komponen itikad baik harus sebagai pembentuk hubungan hukum yang ideal dari awal hingga berakhir, dan realisasi dalam melaksanakan kewajiban merupakan gambaran konkritnya. Komponen garansi memberikan jaminan perlindungan bagi para pihak, dan berbagai regulasi mengatur perbuatan hukum dalam bertransaksi, namun masih berserakan diberbagai komponen pendukung lain yang berupaya pemanfaatan teknologi dalam bertransaksi dapat berkesinambungan.
\end{abstract}

Kata Kunci: kepastian hukum, jual beli, telepon seluler, media elektronik

\section{Introduction}

Along with the development of society and technology, more people use digital technology to connect with others. ${ }^{1}$ Almost every economic activity in the world particularly Indonesia make use of Internet as an electronic system. One of economic activities which make use of internet is e-commerce. ${ }^{2}$

This paper is part of dissertation on Doctoral Program of Law Universitas Muslim Indonesia

Syaibatul Hamidi, et.al., "Bukti Elektronik Dalam Sistem Pembuktian Pidana", Jurnal Ilmu Hukum, Vol. 1 No. 4, 2013, Banda Aceh: Postgraduate Universitas Syiah Kuala, page 25.

2 Rahadi Wasi Bintoro, "Peranan Hukum Dalam Penyelesaian Sengketa Transaksi Elektronik di Peradilan Umum", Jurnal Dinamika Hukum, Vol. 11 No. 2, 2011, Puwokerto: Faculty of Law Universitas Jenderal Soerdiman, page 259.
E-Commerce is one of trading transaction types mostly influenced by the advancement of information technology. Applying this kind of transaction, the concept of traditional market (direct trading) has transformed into telemarketing (trading via internet). E-commerce has changed the way consumers obtain their desired products. $^{3}$ There is a legal relation in e-commerce between seller and buyer. The legal relation which emerges rights and obligations regulated in rule of law is called as legal relation. ${ }^{4}$

3 Alfian Perdana, et.al., "Penyelesaian Wanprestasi Dalam Perjanjian Jual Beli Melalui Media Elektronik", Jurnal Ilmu Hukum, Vol. 2 No. 1, 2014, Banda Aceh: Postgraduate Universitas Syiah Kuala, page 52.

4 Rochani Urip Salami dan Rahadi Wasi Bintoro, "Alternatif Penyelesaian Sengketa Dalam Sengketa Transaksi Eletronik (E-Commerce)", Jurnal Dinamika Hukum, Vol. 
The advancement of information technology including internet, provides its own challenge for legal development especially for Indonesia law to be adjusted with social change. ${ }^{5}$ In Indonesia, the presence of information technology has been regulated by Law Number 11 Year 2008 amended by Law Number 19 Year 2016 on Electronic Transaction (LAW of information technology). LAW of information technology is the first reference to regulate any electronic transaction in Indonesia and provide a legal renewal aimed to accommodate the society necessity to guarantee legal security while doing transaction via electronic media. ${ }^{6}$ In fact, this legal protection did not answer the problem appeared in cellphone trading transaction in Indonesia. Although the change of Law of Information Technology has set, it only added several paragraphs and the explanation did not accommodate concrete dispute in cellphone trading transaction through electronic media. Whereas the object of the study potentially raise conflict in terms of quality degradation of electronic systems in cellphone. Particularly, the loss of quality due to hidden defects or other different items display from the intended items by the buyer are the matter the law cannot accommodate.

Nowadays, cellular phone seemingly becomes people basic need. This matter becomes law reality; therefore, a law is required to organize people's effort so they can have a concrete cellular phone through technology and information utilization.

\section{Problem}

What are the components of law required to apply legal security in providing solution for cellphone transaction dispute through electronic media in Indonesia?

\section{Discussion}

13 No. 2, 2013, Puwokerto: Faculty of Law Universitas Jenderal Soerdiman, page 125.

5 Syaifullah Noor, et.al., "Informasi dan Transaksi Elektronik Dikaitkan Dengan kebebasan Berekspresi", Jurnal Ilmu Hukum, Vol. 3 No. 3, 2015, Banda Aceh: Postgraduate Universitas Syiah Kuala, page 69.

6 Rahadi Wasi Bintoro, Op. Cit., page 260
Legal security is interpreted that one will get something that he/she wants in certain condition. Security can be interpreted as the clarity of norm; thus, it is able to be a guideline for citizen. ${ }^{7}$. The study about legal security on cellphone trading transaction through electronic media analyzes the legal relation between seller and buyer in certain e-commerce. Legal relation which raises rights and obligations basically is regulated in rule of law that is called as legal relation. ${ }^{8}$

Legal relation in e-commerce may apply analogy method related to legal relation for conventional agreement as arranged in BW. This is done by applying provisions of law as arranged in Book III BW to law in e-commerce. The concept of agreement in Book III B is a legal action where one legal subject or more record or tied himself to one legal subject or more. An agreement is valid if it is fulfilled by the elements in Article 1320 Burgelijke Wetboek which decides that the valid requirement of agreement are the agreement of each party, the proficiency in making agreement, things to agree upon and halal things. ${ }^{9}$

The stipulation of Law Number 11 Year 2008 on Electronic Information and Transaction later amended by Law Number 19 Year 2016 on the Amendment of Law Number 11 Year 2008 on Electronic Information and Transaction serves a new legitimation for the solution of electronic system-related dispute.

The most popular electronic transaction practices is cellphone trading. Cellphone transaction starts from the service providers first to make website about the store offering the traded items features, affordable prices, items specification details and its payment method along with the attractive displays.

One of the service providers of cellular phone transaction is Tokopedia. The following is the web view of Tokopedia.

7 Wijayanta, "Asas Kepastian Hukum, Keadilan dan Kemanfaatan Dalam Kaitannya Dengan Keputusan Kepailitan Niaga", Jurnal Dinamika Hukum, Vol. 14 No. 2, 2014, Purwokerto: Faculty of Law Universitas Jenderal Soedirman, page 219 .

8 Rochani Urip Salami and Rahadi Wasi Bintoro, Op.Cit., page 125.

9 Rahadi Wasi Bintoro, Op. Cit., page 261. 
Figure 1. Web View of Tokopedia

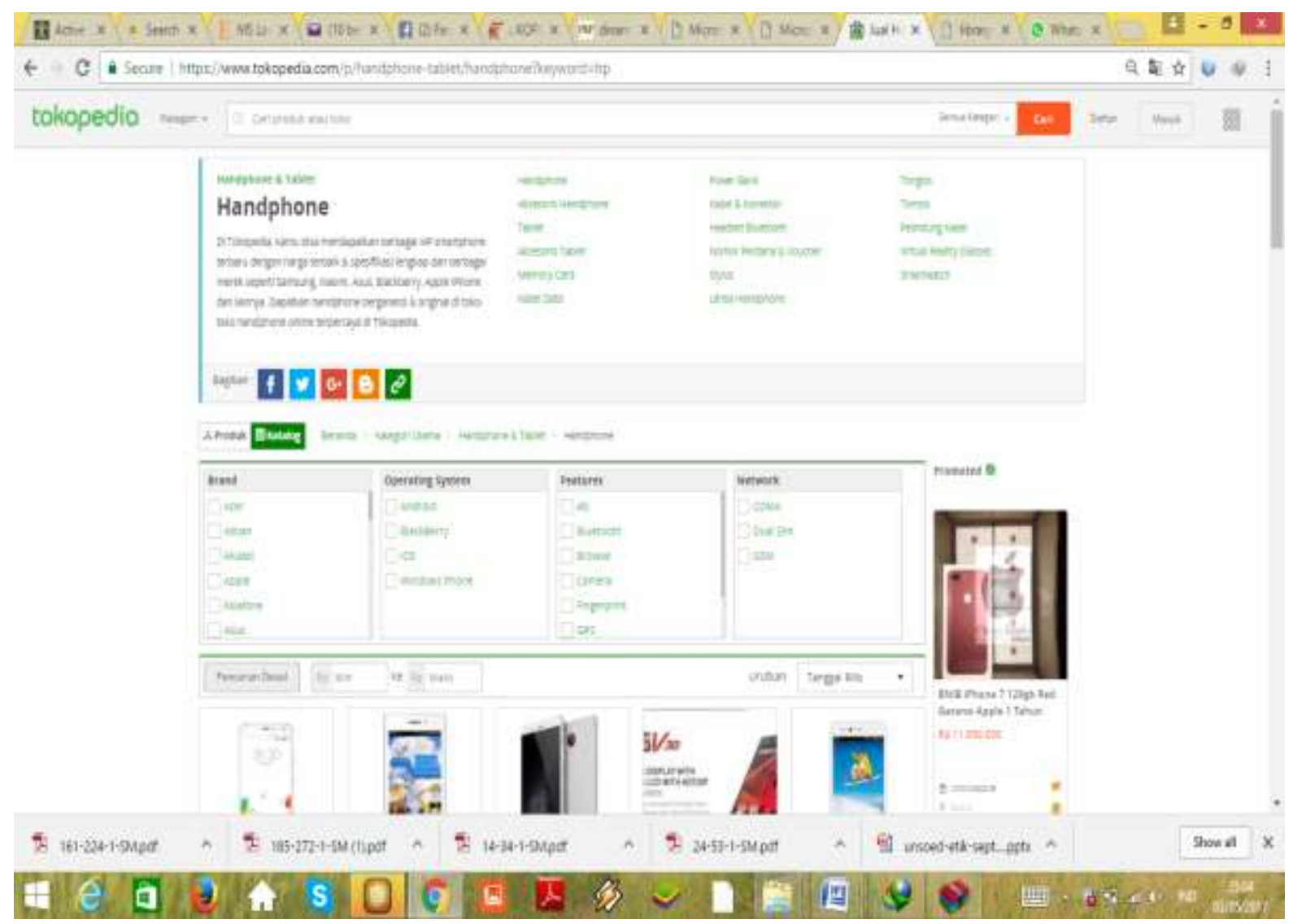

It can be seen that Tokopedia offers various brands of cellphones, specification, warranty, and payment method. These intrigue buyers or consumers to do the transaction by choosing one of the cellphone menu based on their needs.

In fact, one of the tokopedia consumers in Makassar who has been interviewed, Andi Zulkarnain, said :

"I have ever done a transaction in one of the electronic sales services. Yet, my cellphone which I ordered was not as I have expected. They sent me a soap bar instead".

This is very contradictive with Article 1320BW, about halal reason, because in the beginning, the item offered was based on the pictures provided, but consumer have been fraud by those provider. Among illegal online trading webs, three of them are as follows: https://allsalam- elektronik.hourb.com/; https://andika77shop. blogspot.com; https://anitaphoneshop.com ${ }^{10}$

E-commerce fraud seemingly increases. Meanwhile, if it is examined by Law of Information Technology which is lex spesialis, the settlement form of problem that mentioned is not sufficient. This indicates crisis of legal security in cyber world which leads to what so-called chaos theory. ${ }^{11}$ This crisis is used by some people as an opportunity in electronic transaction especially cellphone. Eventhough Law of Information Technology exists, the sanction implementation upon electronic transaction is complicated proccess. I regard to this, a law effort to minimize the complexity through renewal of

10 Tanujaya, Alfons, Kamis, April 18 ${ }^{\text {th }} 2013$, Catat! Ini Daftar Toko Online Abal-abal, Available on: https://inet.de tik.com/security/d-2223902/catat-ini-daftar-toko-on line-abal-abal, Accessed on March $13^{\text {th }} 2017$.

11 Faisal, 2010. "Menggugat Dominasi Positivisme Hukum." Jurnal Hukum Progresif, Vol. 4 No. 1, 2010, Bangka Beli-tung: Faculty of Law Universitas Bangka Belitung, page 1-28. 
concrete action by considering particular components is necessarily made.

Based on those conditions, the following are several components required for the law efforts to provide any form of security and give legal problem solution.

\section{Good Intention}

Good itention (goede trouw) is a mandatory attitude within an action. The actualization of this attitude will be reflected by someone's behaviour and can be felt by others through their perception. Through commonsense, people will feel justice in one's attitude which is objective and in accordance with given norms. Nowadays cellphone is a supra system consisting of complicated system and sub sytem, since today it is developed as multifunction communication devices. Therefore, intentionally hiding sub system deficiency within cellphone electronic system is commonly found, ${ }^{12}$ as well as hijacking personal financial system.

It should be noted that the utilization of electronic media for cellphones is apt to legal infringement for potential fraud. Cell phone is a supra system in an electronic system. Nowadays there are many reassembled inappropriate cell phones are sold in the market. The defected condition of cellphone subsystem is not worth paying for. ${ }^{13}$

Good intention must be perceived by other parties since the beginning of the transaction until the cellphone arrives in their hands. In addition, the sellers must be free from problems, that is, they have to do their business wholeheartedly and cling firmly to the principles of justice, fairness, and appropriateness. Actually, the success and the survival of a business do not only depend on profit, but also the degree to which the business can balance both profit and interest of the public. ${ }^{14}$ Legal action needs component of good intention from each party which can be obtained through clear and

Look at Article 1504 Burgerlijke Wetboek

3 Ibid

14 Zakaria, et.al., "Moral Philosophies Underlying Ethical Judgments", International Journal of Marketing Studies, Vol. 4 No. 2, 2012, North York: Canadian Center of Science and Education, page 103-110. firm legal security. The sanction can be given by the victim through electronic information by giving bad rating to the agent through behavior of appraisal facility in using electronic media. The significant influence of sanction given by the victim to the agent is the costumer distrust in relatively short time regarding its widely open access.

The legal security plays role in establishing people good intention in engaging electronic transaction. Initially, people tend to obey the regulation due to sanction. However, if they are committed, their obedience will be internalized, thus, they will consistently obey the regulation even though they are not supervised. They will always attempt that good intention must exist in the self of every human being.

\section{Performing Obligation}

Performing obligation elicits right since it provide other's right. If everyone fully carries out their obligation, they will fully get their right in return although sometimes standard clause is an agreement containing requirements which tends to benefit the party that prepares or proposes. It is actually not a guarantee to defend pacta sunt servanda in judge's verdict. One day, legal security functions to reduce someone's rights if there is no principle of balance in a contract.

The given legal security has not effectively accommodate the problem of parties engaging cellphone transaction through electronic media; hence, every party should carry out their obligation, whether doing or not doing something to other parties. The strict control provided by the legal security will ensure the good intention and obligation implementation. It will also decrease the potential loss that may once occur to the party by obeying the law which protect the society. By doing so, these parties can enjoy the advantages and are totally satisfied after engaging cellphone transaction through electronic media in Indonesia.

\section{Warranty}

Providing warranty is considered as an opportunities utilization for legal security crisis. Nowadays, people with law awareness demand 
a law protection in form of legal security to secure their right. Marotta-Wurglerf stated:

"this lack of consumer awareness, some fears, allows sellers to offer unfair terms that contractually extend intelectual protections beyond those afforded by federal intelectual property laws, for example, and that limit liability for product failure". ${ }^{15}$

It shows that every party needs a guarantee for law protection through product warranty.

The cellphone warranty removes any worry in case of devices imperfection. This is the factor why parties want a protection assurance, either from the legal security which specifically rules or from the internal law of the institution that attempts to give cellphone protection assurance from both treatment and usage. The warranty is considered to provide solution if concrete dispute occurs. The hidden defect on cellphones practices are expectedly overcome. In addition, even though there is a regulation governing the cellphone utilization appropriateness assurance in many regulations, as a matter of fact, problems about the duration of the warranty consumer may use still arise. The delivery and production process takes much time by the valid period of time for the cellphone warranty.

\section{Supporting Media}

Supporting media consist of Credible Web site, Keep Contact, Rating and Testimonials and Privacy of Personal Data. It can be explained as follows: first, Credible Website. Various ways are developed by electronic agent organizer in exploiting benefits from the lack of legal security for the sake of commercial electronic existence in cyber world. This act is in line with a statement:

"the internet applications layer provides support systems for the internet economy through a variety of software applications (ranging from web page design to security) thet enable organizations to commer-

15 Marotta-Wurglerf, Florencia. "Will Increased Disclosure Help? Evaluating the Recommendations of the ALI's 'Principles of the Law of Software Contracts.'" JSTOR, Vol. 78 Issue. 1, 2011. The University of Chicago Law Review, Page 165-186. cially exploit the backbone infrastructure"16

The result of correspondence elicited from the transaction organizer population stipulates that a eligibility verification is highlighted through the a website authenticity, by means of certain symbols awards indicating the legality of a site obtained from a designated supervisory agency only. It may replace the role of legal security (temporarily) related to the concrete arrangement of transactions, hence, the presented information can be accounted for by every organizer of the transaction.

Feasibility institution also anticipates the dynamics of cyber, sometimes it goes far from the law that provides standard guidelines in transaction. When the role of legal security dec-lines, the role is temporarily handed over by the feasibility institution to continue achieving the positive implications that can be generated by the use of cyber in the transactions of phone and prevent from recurring chaos because the legal security is not clear and firm in Indonesia.

Second, Keep Contact. Keep contact is the establishing a public trust level to constantly utilize electronic media in cellphones transactions through transparent information process until the items are received by customers. In other words, it deals with providing detailed information from the beginning of transaction until the items are at customers' hands. Providing true information is one of seller's duty to establish trust between parties. From the beginning to the end of the legal relation process, there are many obligations imposed to each party to have excellent performance.

As one of the party, correspondent feels that there is an effort of object realization through the lavering process information since confirming other related parties can be done through checking the existence of the object. For instance, the provider may request transfer information within the agreed amount of funds,

\footnotetext{
16 Mahadevan B, "Business Models for Internet-Based ECommerce: An Anatomy", California Management Review, Vol. 42 Issue 4, 2000, California: University of California Press Journals, page 55-69.
} 
and for the consumer may request factual information to the courier assisting the transition of the transacted object.

Third, Rating and Testimonials. The transaction agents commonly concerns about ratings and testimonials provided by parties who have ever engaged transaction. The increasing level of trust is able to affect the scale and circulation of mobile phones as well as acceptance of agreements for providers. Mahadevan and Series stated that:

"the internet infrastructure layer and the applications layer play a crucial role in moderating and setting trends for the growth of the internet economy. ${ }^{17}$

Since the additional application components in a site always work to improve security in cellphone transactions. This practice often indicates that ratings and testimonials contribute to raise the rankings of the providers and customers which also impact on the process of quick and smooth transaction. Due to the high number of achievements made, it increases the level of public trust of electronic transactions on e-commerce which cannot be found on the other site.

Fourth, Privacy of Personal Data. The urge of society in this transaction model is related to personal data which come into consideration. To date, considerable effort has been invested in examining the trust issue in e-commerce, primarily on privacy and security ${ }^{18}$, thus it is undeniable that many fake online cellular use various facilities offered by cyber world (email, social media sites, online advertising, etc.), which attempts to gain a lot of information that can be obtained including financial system information, or the identity of the customer to gain profit against other's rights.

Web marketers through e-mail marketing provide little bit relevant but incomplete information about products and services witch leads to curiosity to gain more information

17 Mahadevan B, Op. Cit., page 55-69.

18 Corbitt, Brian J, Theerasak Thanasankit, and Han Yi. "Trust and E-Commerce: A Study of Consumer Perceptions." Electronic Commerce Research and Applications Vol. 2 Issue 3, 2003, Elsevier, page 203-215. among consumer ${ }^{19}$. The empirical facts, one of the parties takes advantage of the unnoticed aspect in the legal security by assumption that this way can grasp more benefit and ignore the concept of virtue prescribed by law.

\section{Conclusion}

Legal security in Indonesia contains preemptive element as an effort to prevent conflict, and to accommodate various disputes of cellphone transaction through electronic media. To bring the factual cellphone, a good intention must be present since the intention of forming a legal relation until it terminates while the realization in the fulfillment of rights and carry out the obligations is a concrete depiction. The warranty component also provides protection for the parties, and various rules in supporting facilities of electronic system are present to set and standardize a legal deed in transactions. Although various soft wares that attempt to apply the technology in transactions are not in a good order, it has to be done after all to anticipate any potential conflicts that may rise.

\section{Suggestion}

To achieve an effective dispute settlement process, it is advisable to create a reliable situation for the transaction organizers through clear and firm legal security in arrangement on each component. In return, it encourages good behavior during transaction.

\section{References}

B, Mahadevan. "Business Models for InternetBased E-Commerce: An Anatomy". California Management Review. Vol. 42 Issue 4. 2000. California: University of California Press Journals;

Bintoro, Rahadi Wasi. "Peranan Hukum Dalam Penyelesaian Sengketa Transaksi Elektronik di Peradilan Umum". Jurnal Dinamika Hukum. Vol. 11 No. 2. 2011. Puwokerto: Faculty of Law Universitas Jenderal Soedirman;

Corbitt, Brian J. Theerasak Thanasankit. and Han Yi. "Trust and E-Commerce: A Study

19 Kumar, Satinder and Rishi Sharma, "An Empirical Analysis of Unsolicited Commercial E-Mail.” Paradigm, Vol. 18 Issue 1, 2014, SAGE Publications, page 1-19. 
of Consumer Perceptions". Electronic Commerce Research and Applications. Vol. 2 Issue 3. 2003. Amsterdam: Elsevier;

Faisal. "Menggugat Dominasi Positivisme Hukum". Jurnal Hukum Progresif. Vol. 4 No. 1. 2010. Bangka Belitung: Faculty of Law Universitas Bangka Belitung;

Hamidi, Syaibatul. Et.al. "Bukti Elektronik Dalam Sistem Pembuktian Pidana". Jurnal Ilmu Hukum. Vol. 1 No. 4. 2013. Banda Aceh: Postgraduate Program Universitas Syiah Kuala;

Kumar, Satinder and Rishi Sharma. "An Empirical Analysis of Unsolicited Commercial EMail". Paradigm. Vol. 18 Issue 1. 2014. New York: SAGE Publications;

Noor, Syaifullah. Et.al. "Informasi dan Transaksi Elektronik Dikaitkan Dengan kebebasan Berekspresi”. Jurnal Ilmu Hukum. Vol. 3 No. 3. 2015. Banda Aceh: Postgraduate Program Universitas Syiah Kuala;

Perdana, Alfian. Et.al. "Penyelesaian Wanprestasi Dalam Perjanjian Jual Beli Melalui Media Elektronik". Jurnal IImu Hukum. Vol. 2 No. 1. 2014. Banda Aceh: postgraduate Program Universitas Syiah Kuala;

Salami, Rochani Urip dan Rahadi Wasi Bintoro. "Alternatif Penyelesaian Sengketa Dalam
Sengketa Transaksi Eletronik (E-Commerce)". Jurnal Dinamika Hukum. Vol. 13 No. 2. 2013. Puwokerto: Faculty of Law Universitas Jenderal Soerdiman;

Tanujaya, Alfons. Kamis, 18 April 2013. Catat! Ini Daftar Toko Online Abal-abal. Available on: https://inet.detik.com/security/ d-2223902/catat-ini-daftar-toko-onlineabal-abal. Accessed on March $13^{\text {th }} 2017$;

Wijayanta. "Asas Kepastian Hukum, Keadilan dan Kemanfaatan Dalam Kaitannya Dengan Keputusan Kepailitan Niaga". Jurnal Dinamika Hukum. Vol. 14 No. 2. 2014. Purwokerto: Faculty of Law Universitas Jenderal Soerdiman;

Wurglerf, Florencia Marotta. "Will Increased Disclosure Help? Evaluating the Recommendations of the ALI's 'Principles of the Law of Software Contracts". JSTOR. Vol. 78 Issue 1. 2011. Chicago: The University of Chicago Law Review;

Zakaria. Et.al. "Moral Philosophies Underlying Ethical Judgments". International Journal of Marketing Studies. Vol. 4 Issue 2. 2012. North York: Canadian Center of Science and Education. 